\title{
HEALTH STATUS AND BIO-SECURITY PLANS ON PIG FARMS
}

\author{
B. Stanković ${ }^{1}$, S. Hristov ${ }^{1}$, T. J. Bojkovski ${ }^{2}$, N. Maksimović ${ }^{3}$ \\ ${ }^{1}$ Faculty of Agriculture, 11080 Belgrade-Zemun, Republic of Serbia \\ ${ }^{2}$ Faculty of Veterinary Medicine, 11000 Belgrade, Republic of Serbia \\ ${ }^{3}$ Institute for Animal Husbandry, 11080 Belgrade-Zemun, Republic of Serbia \\ Corresponding author: baxton@agrif.bg.ac.rs \\ Review paper
}

Abstract: Preservation of necessary level of swine herd health status is the most important aspect of bio-security, farm production and successful welfare protection. It involves a list of bio-security measures which must be essential part of production technology, including good rearing conditions and other prophylactic measures appliance. According to previously performed investigations, a list of elements required to establish standards for bio-security for particular pig farm was created. The list includes elements related to assure spatial., microclimate and hygienic conditions for pigs rearing, care, nutrition and watering, surveillance, regrouping and transport of swine, disease outbreak control, barns equipment and production process organisation which are performed by veterinarians and zootechnicians.Bio-security standards must concern necessary level of swine herd health status and organization, size and type of operation and anticipate all compulsory measures for health control and disease spreading prevention, particularly those whose outbreak must be reported. In bio-security plan structure present epidemiological situation, potential herd health and production threats, as well as possible solutions must be concerned.

Key words: bio-security, plan, welfare, farm, swine

\section{Introduction}

Preservation of required level of swine herd health status is the most important aspect of bio-security, farm production and animal welfare. This includes deliberate and persistent use of series of bio-security measures that must be part of the production technology, including good housing conditions and use of prophylactic measures. When discuss farm bio-security, it must be emphasized that there are four analogous, but some different concepts: bio-security plans, HACCP (Hazard Analysis and Critical Control Points - HACCP), risk management and urgent situations plans. Bio-security plans are intended to prevent adverse 
situations and improve the business, which, in essence, is the prevention of disease (Uhlehoop, 2007). Plans for emergency situations are made for quick reaction to adverse events in order to continue production (Valčić, 2007).

\section{Organization of health care and bio-security on the farm}

Although based on clear principles, the choice and manner of application of bio-security measures is not unique, due to differences between farms, and referring to their location, epidemiological situation, organization and technology of production, employees, purchase of food and other peculiarities (Stanković and Hristov, 2009). This means that each farm requires its own measures of disease prevention and control and bio-security protocols (Uhlenhoop, 2007; Hristov et al., 2007; Stanković et al., 2008). Regarding bio-security and economy issues, farms with enclosed system of rearing are the best technological solution. Technological design of enclosed farms makes the solid protection against penetration of many infectious diseases, such as viral respiratory diseases, salmonellosis, dysentery, and other diseases. If these infections were already present in the herd, the eradication program on enclosed farms has the highest chance to succeed. In these highly organized farms herd replacement with new animals from other farms can not be performed except through the occasional purchase of conserved sperm of boars with superior genotypes (Anon., 2008).

\section{Comprehensiveness of bio-security measures}

There are strong economical reasons to prevent infectious diseases. Each year, many breeders spent significant amounts of money to suppress diseases which were already outspreaded in herd. These costs are always increased by pigs' mortality and reduced production. Animal welfare, awareness and way of thinking of stockman should also be important motives for measures reducing disease undertake (Hristov et al., 2009). Investigations and farm bio-security assessment showed that during production, omissions often occur allowing infectious agents to penetrate and endanger the entire herd health and production. Such phenomena occur not only as a result of ignorance or lack of information, as is often the case in developing countries, but sometimes producers include certain risk when protective measures cost "to much" as well (Boklund et al., 2004). Animal breeders and manufacturers of animal products have to solve problems concerning preservation of health, welfare and animal production on daily bases (Petrović et al., 2007), facing the fact that the outbreak of many diseases can be prevented, if the times taken appropriate preventive measures are performed. Nevertheless, procedures and measures to prevent the entry and/or spread of disease on farms are rarely 
systematically implemented (Stanković et al., 2005; Hristov et al., 2007). There is no comprehensive surveillance and programs of bio-security measures for most domestic herds; similar situation exists in countries with a developed pig production also. Cardinal elements of bio-security are often (and even deliberately) ignored, such as reliable sources for procurement of new breeding animals and their isolation before introducing into herd (Stanković et al., 2009).

Generally, four levels of farm bio-security could be described: 1) the highest, when the newly acquired pigs are not purchased from outside and own are not presented on exhibitions and fairs, 2) relatively high, when the newly acquired animals are not purchased from outside, but own are presented on exhibitions and fairs for the sale, 3) high, when the newly acquired gilts and boars are purchased from other farms, but kept in quarantine before introduction into the herd, and 4) the lowest, when the animals are purchased from other, often different sources and are not placed in quarantine on arrival., but are directly introduced into herd, where at the farm in situ is isolation barn, as well as those farms where the staff serves their own and newly acquired animals as well. The lowest bio-security level does not accomplish necessary function of isolation, but only acclimatization of newly purchased pigs (Anon., 2008).

In many of the acquisitions, newly purchased pigs vary in age, often with different geographical origin and health background, gathered in a limited space. Genetically conditioned hormonal imbalance of highly productive breeds (Hristov and Bešlin, 1991) makes these pigs highly sensitive to stress and more susceptible to infections (Stanković et al., 2007b; Stanković et al., 2007c). Oversights, failures and mistakes in necessary bio-security level maintaining usually lead to diseases outbreaks, production decrease, higher mortality and loss of income, thus endangering the survival of entire herd (Stanković et al., 2007a). These factors indicate the bio-security status of a farm, but their mutual interaction and thorough action must be emphasized as well.

\section{Measures to achieve the desired level of herd health status}

According to conducted investigations, a list consisting of basic elements of health status and bio-security which are essential for the development and creation of bio-security plans and welfare standards for each specific situation on pig farms was established. The list contains elements that are related to general hygiene measures, monitoring, moving and handling, implementation of measures to prevent disease, evaluation of physical fitness, equipment and stable organization of the technological process of production, guidelines and recommendations of general and individual bio-security measures, which should be implemented by stockmen, zootechnicians and veterinarians. 
Good health is essential for efficient production and it includes high quality accommodation, particularly hygiene, ventilation and well timed and effective prophylaxis. Therefore, a bio-security plan should include: a written plan for achieving and maintaining desired levels of bio-security, including the procurement procedure, delivering, isolation and introduction of new animals, specific disease control programs, such as salmonellosis, erysipelas, colibacillosis, mycoplasmosis and parvovirosis, vaccination program, parasite control, extremities care and prevention of bad habits like tail biting (Stanković et al., 2008).

Bio-security involves the removal or reduction of specific factors (effective disease control systems, such as vaccination and dehelmintization) and non specific factors (through the proper ways of rearing and breeding, good hygiene, reduction of exposure of pigs to all forms of stress) of disease outbreaks and spread to a minimum. Specific characteristics of infectious agents and ways of their spreading must be considered, including via rodents, birds, and other types of domestic and wild animals, as well as the possibility of spreading by air. A significant measure of herd health control and comfort is assessment of body condition, because it enables direct insight into successful ways of growing and therefore prevention of "expensive" welfare problems. It is a simple technique which routinely evaluates physical condition and animal's body reserves depending on particular production purpose (Anon., 2008; Bojkovski et al., 2009), such as the evaluation of physical fitness of sows at different stages of reproductive cycle. Sick or injured animals should be given the necessary veterinary help without delay, and if there is suspicion that there is any infectious disease, they must be isolated appropriately. Lameness indicates that animals suffer as a result of impaired health or discomfort, especially when it occurs simultaneously at several animals, and directly affects the production. Presence of larger number of pig parasites increases the possibility of infectious diseases. Immediate isolation and informing the competent veterinarian are obligatory if there is suspicion that the obligatory reportable disease outbreaks in farm, such as classical or African swine fever, anthrax, Aujeszky's disease, foot and mouth, rabies, vesicular disease, Teschen disease etc. (Anon., 2008).

Finally, it is necessary to maintain understandable and detailed documentation related to all notified conditions, all applied medical procedures and all mortality during production. These data should be kept for at least three years of treatment, or the last inspection (Anon., 2008).

\section{Conclusion}

According to presented facts, it could be concluded that:

Bio-security standards must take into account the necessary level of herd health and the organization, capacity and type of production on farm; 
Bio-security plan must predict all the necessary measures to control herd health and prevent entry and spread of infectious diseases, especially those whose existence must be reported;

When making concrete bio-security plans current epidemiological situation, predicted potential threats and response measures must be taken into account as well.

\title{
Acknowledgment
}

This paper was financed by Ministry of Science, Republic of Serbia, Project TR 20110 "Development and implementation of welfare and bio-security standards in cattle and pig production technology improvement".

\section{Zdravstveni status i biosigurnosni planovi na farmama svinja}

\author{
B. Stanković, S. Hristov, J. Bojkovski, N. Maksimović
}

\section{Rezime}

Očuvanje potrebnog nivoa zdravstvenog stanja populacije je najvažniji aspekt očuvanja biosigurnosti i uspeha proizvodnje, kao i dobrobiti svinja, i podrazumeva niz biosigurnosnih mera koje moraju biti sastavni deo proizvodne tehnologije, uključujući dobre uslove smeštaja i držanja i primenu profilaktičkih mera. Na osnovu sprovedenih istraživanja je sastavljena lista elemenata neophodnih za uspostavljanje standarda i izradu planova biosigurnosti za konkretnu farmu svinja. Lista sadrži elemente koji se odnose na obezbeđenja prostornih, mikroklimatskih i higijenskih uslova gajenja životinja, negu, ishranu i napajanje, nadzor, pregrupisavanje i transport životinja, mera za sprečavanje pojave bolesti, opremanje staja i organizacija tehnološkog procesa proizvodnje, koje sprovode odgajivači, veterinarski i zootehnički stručnjaci.

Standardi biosigurnosti moraju uzeti u obzir neophodan nivo zdravstvenog stanja zapata svinja, organizaciju, obim i vid proizvodnje na farmi i predvideti sve neophodne mere za kontrolu zdravstvenog stanja zapata i sprečavanje unošenja i širenja infektivnih bolesti, posebno onih čije se postojanje mora prijaviti. Pri izradi konkretnih planova biosigurnosti mora se uzeti u obzir trenutna epizootiološka situacija, ali i predvideti potencijalne pretnje po zdrastveno stanje i proizvodnju na farmi i moguća rešenja. 


\section{References}

ANON. (2003): Code of Recommendations for the Welfare of Livestock. Defra Publications, Admail 6000, London, SW1A 2XX, ${ }^{\circ}$ Crown Copyright March 2003PB 7950, http://www.defra.gov.uk/animalh/welfare/farmed/pigs/pigcode.pdf.

ANON. (2008): Merck Veterinary Manual., http://www.merckvetmanual.com/mvm/index.jsp?cfile=htm/bc/180202.htm.

BOJKOVSKI J., STANKOVIĆ B., PETRUJKIĆ T., RADOJIČIĆ B. (2009): Uzgojne bolesti, telesna kondicija i biosigurnosne mere na farmama svinja industrijskog tipa. Veterinarski žurnal Republike Srpske, 9, 1, 43-52.

BOKLUND A., ALBAN L., MORTENSEN S., HOUE H. (2004): Biosecurity in 116 Danish fattening swineherds: descriptive results and factor analysis. Preventive Veterinary Medicine, 66, 1-4, 49-62.

HRISTOV S., BEŠLIN R. (1991): Stres domaćih životinja. Poljoprivredni fakultet, Beograd.

HRISTOV S., STANKOVIĆ B., JOKSIMOVIĆ-TODOROVIĆ M., DAVIDOVIĆ V. (2007): Biosigurnosne mere na farmama goveda. Međunarodna konferencija o doborbiti i biosigurnosti na farmama u Srbiji, Beograd-Zemun, 14.-15. 11. 2007. godine, 259-269.

HRISTOV S., STANKOVIĆ B. (2009): Najznačajniji propusti u obezbeđenju dobrobiti životinja na farmama goveda i svinja. Zbornik naučnih radova XXIII Savetovanja agronoma, veterinara i tehnologa, Beograd, 12.-13.02. 2009. godine, 15, 3-4, 95-102.

PETROVIĆ M., STANKOVIĆ B., HRISTOV S., JOKSIMOVIĆ-TODOROVIĆ M., DAVIDOVIĆ, V., BOŽIĆ A. (2007): Minimalni standardi o uslovima gajenja i dobrobiti svinja. Međunarodna konferencija o doborbiti i biosigurnosti na farmama u Srbiji, Beograd-Zemun, 14.-15. 11. 2007. godine, 173-185.

STANKOVIĆ B., PETRUJKIĆ T., HRISTOV S., RELIĆ R., PETROVIĆ M., RADOJKOVIĆ. D. (2005): Najznačajnije higijensko-sanitarne mere u tehnologiji veštačkog osemenjavanja svinja. Zbornik naučnih radova XVI Savetovanja DDD u zaštiti životne sredine, Banja Vrujci, 28.-31.05. 2005. godine, 247-256.

STANKOVIĆ B., HRISTOV S., JOKSIMOVIĆ-TODOROVIĆ M., DAVIDOVIĆ V., BOŽIĆ, A. (2007a): Biosigurnost na farmi svinja. Međunarodna konferencija o doborbiti i biosigurnosti na farmama u Srbiji, Beograd-Zemun, 14.-15. 11. 2007. godine, 299-310.

STANKOVIĆ, B., HRISTOV, S., PETRUJKIĆ, T., MARINKOVIĆ, M., BAGLOJEVIĆ, M., PETRUJKIĆ B., TODOROVIĆ-JOKSIMOVIĆ M., DAVIDOVIĆ V. ZLATANOVIĆ Z. (2007b): Biosigurnosne mere i standardi u proizvodnji semena nerastova na farmama i u centrima za reprodukciju. Zbornik kratkih sadržaja sa Simpozijuma Veterinarska medicina, stočarstvo i ekonomika u proizvodnji zdravstveno bezbedne hrane, Herceg Novi, 24.06.-01.07. 2007. godine, 47. 
STANKOVIĆ B., HRISTOV S., PETRUJKIĆ T., RELIČ R., PETROVIĆ M., TODOROVIĆ-JOKSIMOVIĆ M., DAVIDOVIĆ V. (2007c): Polno prenosive bolesti svinja. Savremena Poljoprivreda, 56, 1-2, 99-105.

STANKOVIĆ B., HRISTOV S., PETRUJKIĆ T., TODOROVIĆ-MAKISMOVIĆ M., DAVIDOVIĆ, V., BOJKOVSKI, J. (2008): Biosigurnost na farmi svinja u svakodnevnoj praksi, Biotehnologija u spočarstvu, 24, spec.issue, 601-608.

STANKOVIĆ B., HRISTOV S. (2009): Najčešći propusti u obezbeđenju biosigurnosti na farmama goveda $\mathrm{i}$ svinja. Zbornik naučnih radova XXIII Savetovanja agronoma, veterinara i tehnologa, Beograd, 12.-13.02. 2009. godine, 15, 3-4,103-110.

UHLENHOOP E. (2007): Biosecurity planning for livestock farms. Međunarodna konferencija o doborbiti i biosigurnosti na farmama u Srbiji, Beograd-Zemun, 14.15. 11. 2007. godine, 227-237.

VALČIĆ M. (2007): Osnovni kriterijumi i principi pripreme nacionalnij planova u kontroli, suzbijanju i iskorenjivanju zaraznih bolesti životinja. Međunarodna konferencija o doborbiti i biosigurnosti na farmama u Srbiji, Beograd-Zemun, 14.15. 11. 2007. godine, 239-250.

Received 2 February 2010; accepted for publication 22 February 2010 